\title{
Regarding your article "Baseline time accounting: considering global land use dynamics when estimating the climate impact of indirect land use change caused by biofuels." Int J Life Cycle Assess 18(2):319-330. doi: 10.1007/s11367-012-0488-6
}

\author{
Jeremy I. Martin
}

Received: 14 December 2012 / Accepted: 21 February 2013 /Published online: 24 April 2013

(C) Springer-Verlag Berlin Heidelberg 2013

\begin{abstract}
"Baseline time accounting" does not eliminate the need to choose a timeframe, which remains among the most critical parameters in assessing indirect land use change emissions.

The baseline time accounting paper of Kløverpris and Mueller (2013) provides an interesting perspective on an important issue, but the value of their insight is diminished by the failure to include a full consideration of the importance of the timeframe of the analysis. Their examples reevaluate analyses of two existing indirect land use change (ILUC) studies, both of which were based on a 30-year timeframe (Searchinger et al. 2008; Hertel et al. 2010). The baseline time accounting approach uses a 100-year timeframe and the results "are significantly lower $(60$ $70 \%$ ) than the ILUC factors based on the 30-year annualization method." It should come as no great surprise that changing the denominator of a fraction from 30 to 100 reduces that number by $70 \%$.

The authors assert that their approach removes the need to consider arbitrary timeframes. Their decision to use the global warming potential based on a 100 -year timeframe (GWP100) is, they say, "simply ensuring consistency between the ILUC factor estimation and the GWP concept." But 100 years is certainly not the only timeframe that is routinely used in GWP analyses. If the authors had included in their sensitivity analysis the use of GWP20 and GWP500 or constructed a GWP30 that was consistent with the Hertel and Searchinger analyses, the key importance of the choice
\end{abstract}

\section{J. I. Martin $(\bowtie)$}

Clean Vehicles Program, Union of Concerned Scientists, $1825 \mathrm{~K}$

Street NW, Suite 800 ,

Washington, DC 20006-1232, USA

e-mail: jmartin@ucsusa.org of timeframe would have been clear. The authors discuss other papers that make similar use of the GWP methodology, and most of these papers explicitly investigate the effect of timeframe. For example, Cherubini et al. (2011) include results for GWP20, GWP100, and GWP500 in all cases.

The baseline accounting methodology converts a prediction problem into a time shift problem. The question of how to compare deforestation/reforestation today with deforestation/reforestation next year clearly requires a methodology to place a value on time preference. The baseline time accounting methodology does not eliminate the need to make a decision about the timeframe for analysis and, in fact, the decision to adopt a 100-year timeframe is the single largest factor that differentiates the results of the baseline time accounting methodology from simpler approaches.

\section{References}

Cherubini F, Peters GP, Berntsen T, Strømman AH, Hertwich E (2011) $\mathrm{CO} 2$ emissions from biomass combustion for bioenergy: atmospheric decay and contribution to global warming. GCB Bioenergy 3:413-426

Hertel TW, Golub AA, Jones AD, O'Hare M, Plevin RJ, Kammen DM (2010) Effects of US maize ethanol on global land use and greenhouse gas emissions: estimating market-mediated responses. Bioscience 60:223-231

Searchinger T, Heimlich R, Houghton RA, Dong F, Elobeid A, Fabiosa J, Tokgoz S, Hayes D, Tun HY (2008) Use of U.S. croplands for biofuels increases greenhouse gases through emissions from land use change. Science 319:1238-1240

Kløverpris JH, Mueller S (2013) Baseline time accounting: considering global land use dynamics when estimating the climate impact of indirect land use change caused by biofuels. Int J Life Cycle Assess 18(2):319-330. doi:10.1007/s11367-012-0488-6 